\title{
ANALISIS HASIL FERMENTASI PEMBUATAN BIOETANOL DENGAN VARIASI WAKTU MENGGUNAKAN BAHAN (SINGKONG, BERAS KETAN HITAM DAN BERAS KETAN PUTIH)
}

\author{
Andrie Yeremia Marchelino Simanjuntak ${ }^{1)}$, Rachmat Subagyo ${ }^{2)}$ \\ ${ }^{1,2}$ Program Studi Teknik Mesin \\ Fakultas Teknik Universitas Lambung Mangkurat \\ Jl. Akhmad Yani Km. 36 Banjarbaru, Kalimantan Selatan, 70714 \\ e-mail: juntakandrie@gmail.com
}

\begin{abstract}
This study aims to determine the levels of bioethanol from (cassava, black sticky rice, and white sticky rice) with the addition of 10 grams of yeast mass, with a variation of fermentation time of 48 hours, 72 hours and 96 hours and knowing the ethanol levels in accordance with National Standards Indonesia (SNI). This research was carried out by hydrolysis or boiling of ingredients (cassava, black sticky rice, and white sticky rice) using $800 \mathrm{ml}$ of distilled water with 30 minutes, then fermentation using yeast or (saccharomyces cereviseae) and distillation using a tool. Complete destilator to obtain ethanol from fermentation results which is then tested with a pen refractometer to determine whether or not ethanol is formed from the distillation process. The samples were then tested for ethanol content using the Gas Chromatography tool. The results of this study are known by conducting a test using the Gas Chromatography tool to determine the ethanol content contained in the distilled sample. The results of cassava ethanol content with 72 hours fermentation time with ethanol were $98.41 \%$, black sticky rice with 96 hours fermentation time the ethanol content was $94.96 \%$, and white sticky rice with 96 hours fermentation time the ethanol content was $96.67 \%$.
\end{abstract}

Keywords: Cassava, Black Sticky Rice, White Sticky Rice, Time Fermentation, Ethanol

\section{PENDAHULUAN}

Bahan bakar fosil (minyak bumi, gas dan batu bara) sebagai sumber energi yang tidak terbarukan memiliki banyak masalah, terutama kenaikan harga (price escalation) secara global setiap terjadi krisis energi akibat dari faktor-faktor seperti cadangan yang berkurang sesuai dengan umur eksploitasinya. Permintaan yang meningkat, jaminan pasokan (supply security) yang terbatas dan pembatasan produksi pada penilaian dampak lingkungan yang ketat terhadap pemanasan global (global warming), harus dikurangi ketergantungannya. Solusi dalam permaslahan ini adalah menggunakan sumbersumber energi lainnya sebagai bahan bakar alternatif.

Bioetanol merupakan salah satu sumber bahan bakar alternatif yang diolah dari tumbuhan, dimana memiliki keunggulan mampu menurunkan emisi $\mathrm{CO}_{2}$ hingga $18 \%$. Menurut Balai Besar Teknologi Pati (B2TP) ada 3 kelompok tanaman sumber bioetanol yaitu: tanaman yang mengandung pati (seperti singkong, kelapa sawit, tengkawang, kelapa, kapuk, jarak pagar, rambutan, sirsak, malapari, dan nyamplung), bergula (seperti tetes tebu atau molase, nira aren, nira tebu, dan nira surgum manis) dan serat selulosa (seperti batang sorgum, batang pisang, jerami, dan kayu).

Dalam pembuatan bioetanol karbohidrat merupakan bahan baku yang menunjang dalam proses fermentasi, dimana prinsip dasar fermentasi adalah degradasi komponen pati oleh enzim (Rustriningsih, 2007). Fermentasi 
mempunyai pengertian aplikasi metabolisme mikroba untuk mengubah bahan baku menjadi produk yang bernilai lebih tinggi, seperti asam-asam organik, protein sel tunggal, antibiotika dan biopolimer (Muhidin dkk., 2001).

Bioetanol adalah cairan biokimia dari proses fermentasi gula dari sumber karbohidrat menggunakan bantuan mikroorganisme. Bioetanol saat ini yang diproduksi umumnya berasal dari etanol generasi pertama, yaitu etanol yang dibuat dari gula (tebu, molases) atau pati-patian (jagung, singkong, dll). Bahanbahan tersebut adalah bahan pangan (Prastowo, 2007).

Pemutusan rantai polimer tersebut dapat dilakukan dengan berbagai metode, misalnya secara enzimatis, kimiawi ataupun kombinasi keduanya. Proses berikutnya adalah proses fermentasi untuk mengkonversi glukosa (gula) menjadi etanol dan $\mathrm{CO}_{2}$. Arah pengembangan bioetanol mulai berubah generasi kedua, yaitu limbah pertanian yang mengandung selulosa, hemiselulosa, dan lignin. Selulosa merupakan karbohidrat utama yang di sintesis oleh tanaman dan menempati hampir $60 \%$ komponen penyusun struktur tanaman.

Jumlah selulosa di alam sangat melimpah sebagai sisa tanaman atau dalam bentuk limbah pertanian seperti jerami padi, tongkol jagung, gandum dan kedelai. Nilai ekonomi senyawa selulosa pada limbah tersebut sangat rendah karena tidak dapat langsung dimanfaatkan oleh manusia. Sulitnya mendegradasi limbah tersebut menyebabkan petani lebih suka membakar limbah tersebut.

(Bio)Etanol sering ditulis dengan rumus $\mathrm{EtOH}$. Rumus molekul etanol adalah $\mathrm{C}_{2} \mathrm{H}_{5} \mathrm{OH}$ atau rumus empiris $\mathrm{C}_{2} \mathrm{H}_{6} \mathrm{O}$ atau rumus bangunnya $\mathrm{CH}_{3}-\mathrm{CH}_{2}-\mathrm{OH}$. (Bio)Etanol merupakan bagian dari kelompok metil $\left(\mathrm{CH}_{3^{-}}\right)$yang terangkai pada kelompok metilen $\left(-\mathrm{CH}_{2-}\right)$ dan terangkai dengan kelompok hidroksil $(-\mathrm{OH})$. Secara umum akronim dari (Bio)Etanol adalah EtOH (Ethyl- $(\mathrm{OH})$.

Salah satu bahan pokok yang baik digunakan untuk menghasilkan bioetanol adalah singkong/ubi kayu dengan jumlah karbohidrat sebesar 34,00 gram. Namun pada saat ini Badan Ketahanan Pangan Kementerian Pertanian Indonesia sedang mengadakan program "Mengangkat Gengsi Singkong untuk Memperkuat Ketahanan Pangan Alternatif" sehingga singkong lebih diutamakan untuk persediaan bahan pangan.

Kandungan pati yang tinggi pada ubi kayu merupakan substrat yang baik untuk menghasilkan glukosa sebagai produk pembuatan etanol. Sebagai bahan baku, bahan baku dapat digunakan dalam bentuk segar dan chips. Pada dasarnya proses pengolahan ubi kayu menjadi etanol meliputi gelatinisasi pati, diikuti hidrolisis pati secara enzimatis menjadi glukosa dengan menggunakan enzim $\propto$-amilase dan glukoamilase yang selanjutnya difermantasi menjadi etanol dengan bantuan yeast atau bakteri (Anonimous, 2012).

Kemudian ketan hitam juga merupakan salah satu komoditi yang sangat potensial sebagai sumber karbohidrat, antioksidan, senyawa bioaktif, dan serat yang penting bagi kesehatan (Yanuar, 2009). Beras ketan hitam merupakan varietas beras yang patinya mengandung amilopektin sebesar $92-98 \%$ dan jumlah karbohidrat sebesar 74,5 gram. Hal ini mengakibatkan beras ketan hitam memiliki karakteristik lekat atau lengket setelah dikukus. Salah satu potensi lain beras ketan hitam adalah kandungan seratnya yang sangat tinggi karena dalam pengolahannya beras ketan hitam tidak mengalami proses penyosohan.

Selanjutnya ada beras ketan putih yang merupakan salah satu varietas dari padi yang merupakan tumbuhan semusim dengan jumlah karbohidrat yang sangat besar yaitu 79,4 gram. Helaian daun berbentuk garis dengan panjang 15$50 \mathrm{~cm}$. Pada waktu masak, buahnya yang berwarna ada yang rontok dan ada yang tidak. Buah yang dihasilkan dari tanaman ini berbeda ada yang kaya pati dan ini disebut beras, sedangkan buah kaya perekat disebut ketan (Hasanah, 2008). 
Di dalam penelitian ini juga menggunakan proses hidrolis yang merupakan reaksi kimia yang memecah molekul menjadi dua bagian dengan penambahan molekul air $\left(\mathrm{H}_{2} \mathrm{O}\right)$, dengan tujuan untuk mengkonversi polisakarida menjadi monomer-monomer sederhana. Satu bagian dari molekul memiliki ion hidrogen $\left(\mathrm{H}^{+}\right)$dan bagian lain memiliki ion hidroksil $\left(\mathrm{OH}^{-}\right)$. Umumnya hidrolisis ini terjadi saat garam dari asam lemah atau basa lemah (atau keduanya) terlarut di dalam air. Reaksi umumnya yakni sebagai berikut:

$\mathrm{AB}+\mathrm{H}_{2} \mathrm{O} \rightarrow \mathrm{AH}+\mathrm{BOH}$

Akan tetapi, dalam kondisi normal hanya beberapa reaksi yang dapat terjadi antara air dengan komponen organik. Penambahan asam, basa, atau enzim umumnya dilakukan untuk membuat reaksi hidrolisis dapat terjadi pada kondisi penambahan air tidak memberikan efek hidrolisis. Asam, basa maupun enzim dalam reaksi hidrolisis disebut sebagai katalis, yakni zat yang dapat mempercepat terjadinya reaksi (Lowry, 1951).

Fermentasi arti kata fermnetasi selama ini berubah-ubah. Kata fermentasi berasal dari Bahasa Latin "fervere" yang berarti merebus (to boil). Arti kata dari Bahasa Latin tersebut dapat dikaitkan dengan kondisi cairan bergelembung atau mendidih. Keadaan ini disebabkan adanya aktivitas ragi pada ekstraksi buahbuahan atau biji-bijian (Suprihatin, 2010). Ragi mengubah gula menjadi etanol dan karbon dioksida sesuai rumus di bawah ini:

$\mathrm{C}_{6} \mathrm{H}_{12} \mathrm{O}_{6} \rightarrow 2 \mathrm{C}_{2} \mathrm{H}_{5} \mathrm{OH}+2 \mathrm{CO}_{2}$

Gelembung-gelembung karbondioksida dihasilkan dari katabolisme anaerobik terhadap kandungan gula. Fermentasi mempunyai arti yang berbeda bagi ahli biokimia dan mikrobiologi industri. Arti fermentasi pada bidang biokimia di hubungkan dengan pembangkitan energi oleh katabolisme senyawa organik. Pada bidang mikrobiologi industri, fermentasi mempunyai arti yang lebih luas, yang mengGambarkan setiap proses untuk menghasilkan produk dari pembiakan mikroorganisme.

Setelah selesai fermentasi kemudia dilanjutkan dengan destilasi yang merupakan penguapan cairan dan pengembunan kembali uap tersebut pada suhu titik didih. Titik didih suatu cairan adalah suhu dimana tekanan uapnya sama dengan tekanan atmosfer. Cairan yang diembunkan kembali disebut destilat. Tujuan destilasi adalah pemurnian zat cair pada titik didihnya, dan memisahkan cairan tersebut dari zat padat yang terlarut atau dari zat cair lainnya yang mempunyai perbedaan titik didih cairan murni. Pada destilasi biasa, tekanan uap di atas cairan adalah tekanan atmosfer (titik didih normal). Untuk senyawa murni, suhu yang tercatat pada termometer yang ditempatkan pada tempat terjadinya proses destilasi adalah sama dengan titik didih destilat (Sahidin, 2008).

Destilasi sederhana atau destilasi biasa adalah teknik pemisahan kimia untuk memisahkan dua atau lebih komponen yang memiliki perbedaan titik didih yang jauh. Suatu campuran dapat dipisahkan dengan destilasi biasa ini untuk memperoleh senyawa murninya. Senyawa-senyawa yang terdapat dalam campuran akan menguap pada saat mencapai titik didih masing - masing. 


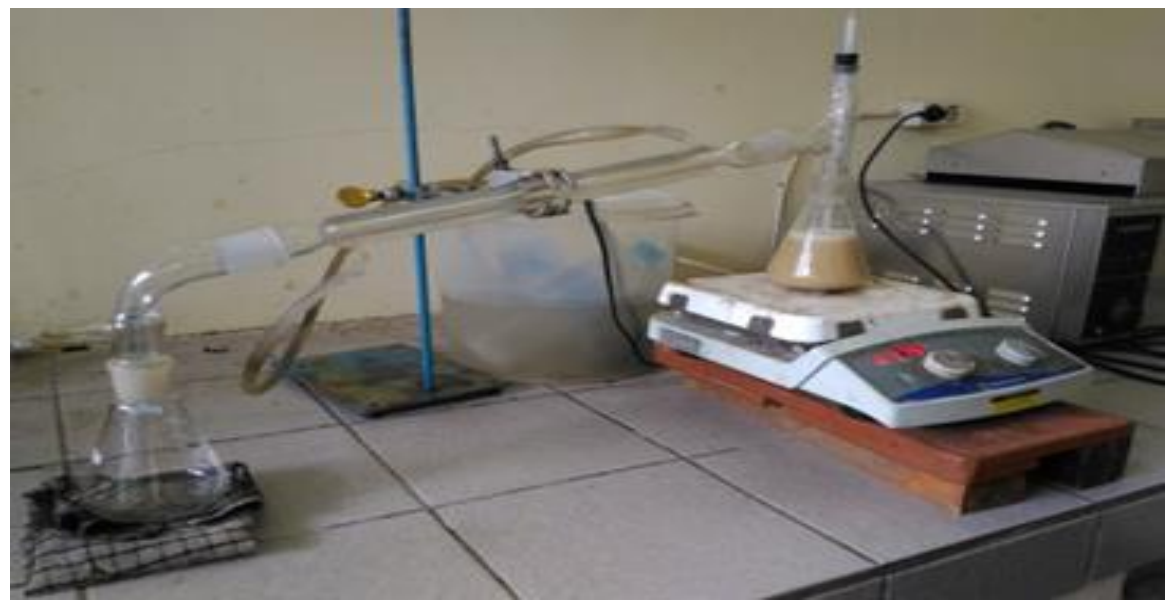

Gambar 1. Destilasi Sederhana

Dalam pemanfaatan bioetanol diarahkan untuk memberikan kontribusi yang signifikan terhadap bauran energi nasional (national energy mix) terutama sebagai bahan bakar pencampur ataupun pensubstitusi bensin. Pemerintah melalui Dewan Standarisasi Nasional (DSI) telah menetapkan Standar Nasional Indonesia (SNI) untuk bioetanol dengan tujuan melindungi konsumen (dari segi mutu), produsen, dan mendukung perkembangan industri bioetanol. Di Indonesia kadar etanol minimum yang digunakan sebagai bahan bakar jenis bioetanol sebesar $(94,0-99,5 \%)$.

Standar Nasional Indonesia (SNI) bioetanol disusun oleh Panitia Teknis Energi Baru dan Terbarukan (PTEB) melalui tahapan - tahapan baku tata cara perumusan standar nasional. Penyusunan SNI bioetanol Terdenaturasi untuk gasohol ini dilakukan dengan memperhatikan standar sejenis yang sudah berlaku di negara-negara lain yang pemakaian bioetanolnya sudah luas dan mencapai tahap komersial. Faktor lain yang juga diperhatikan adalah keberagaman bahan baku bioetanol di tanah air (Badan Standar Indonesia, 2012).

SNI ini disusun oleh Panitia Teknis Perumusan Standar Nasional Indonesia 27-04: Bioenergi melalui proses/prosedur perumusan standar dan terakhir dibahas dalam Forum Konsensus Panitia Teknis Bioenergi di Bali pada tanggal 1 Desember 2011, yang dihadiri oleh anggota panitia teknis dan narasumber terkait.

SNI bioetanol ini merupakan revisi dari SNI 7390:2008, bioetanol terdenaturasi untuk gasohol, yang disusun dengan memperhatikan masukan dari konsumen, produsen dan penyalur serta standar sejenis yang sudah berlaku di negara-negara lain yang pemakaian bioetanolnya sudah luas dan mencapai tahap komersial. Secara substansial perubahan dari SNI 7390:2008 adalah perubahan syarat kadar metanol, penambahan denaturan baru denatonium benzoat, perubahan kadar air, perubahan kadar klorin, dan penghapusan parameter $\mathrm{pH}$.

\section{METODE PENELITIAN}

Metode yang digunakan dalam penelitian ini adalah metode eksperimen. Singkong, Beras ketan hitam, dan Beras ketan putih di fermentasi dengan menggunakan ragi sebanyak 10 gram dan variasi waktu 48 jam, 72 jam, dan 96 jam, kemudian hasil fermentasi di destilasi dengan suhu $90^{\circ} \mathrm{C}$. Selanjutnya hasil dari destilasi di uji di laboratorium untuk mengetahui kadar etanol nya. 


\section{Alat dan Bahan Penelitian}

Botol, balon, kompor, timbangan digital, gelas ukur, sepaket alat destilasi, mikroskop,panci,spatula,corong, pen refractometer, gas chromatograpy.

Singkong, beras ketan hitam, dan beras ketan putih merupakan bahan baku utama dan ragi roti (Saccharomeyces Cereviseae) fermipan.

\section{Pengolahan Bahan}

Singkong dikupas lalu dipotong-potong kemudian dikeringkan lalu ditumbuk hingga halus, untuk beras ketan hitam dan beras ketan putih digiling menggunakan mesin penggiling beras.

\section{Proses Hidrolisis}

Timbang masing-masing tepung dari singkong, beras ketan hitam dan beras ketan putih sebanyak 100 gram. Kemudian dicampur dengan air aquades sebanyak $800 \mathrm{ml}$, campuran direbus selama 30 menit dengan suhu $100^{\circ} \mathrm{C}$ sambil diaduk

\section{Proses Fermentasi}

Siapkan botol untuk tempat fermentasi, hasil hidrolisis didinginkan sampai suhu $30^{\circ} \mathrm{C}$, campurkan ragi 10 gram, tutup mulut botol dengan balon, variasikan waktu fermentasi 48, 72 dan 96 jam

\section{Proses Destilasi}

Memanaskan campuran larutan hasil fermentasi pada suhu $90^{\circ} \mathrm{C}$ setara titik didih etanol selama 2 jam, uap etanol mengalir melalui pipa kondensor sehingga kembali menjadi etanol cair.

\section{Pengujian Sampel Etanol}

Pengujian dilakukan dengan menggunakan alat pen refractometer untuk mengetahui kadar etanol yang terbentuk, kadar etanol tertinggi dari hasil uji dengan pen refractometer dilakukan pengujian dengan alat gas chromatography untuk mengetahui kadar etanol sebenarnya karena alat gas chromatography hasil lebih akurat. 


\section{Diagram Alir Penelitian}

Diagram alir penelitian ini dapat dilihat pada Gambar 2.

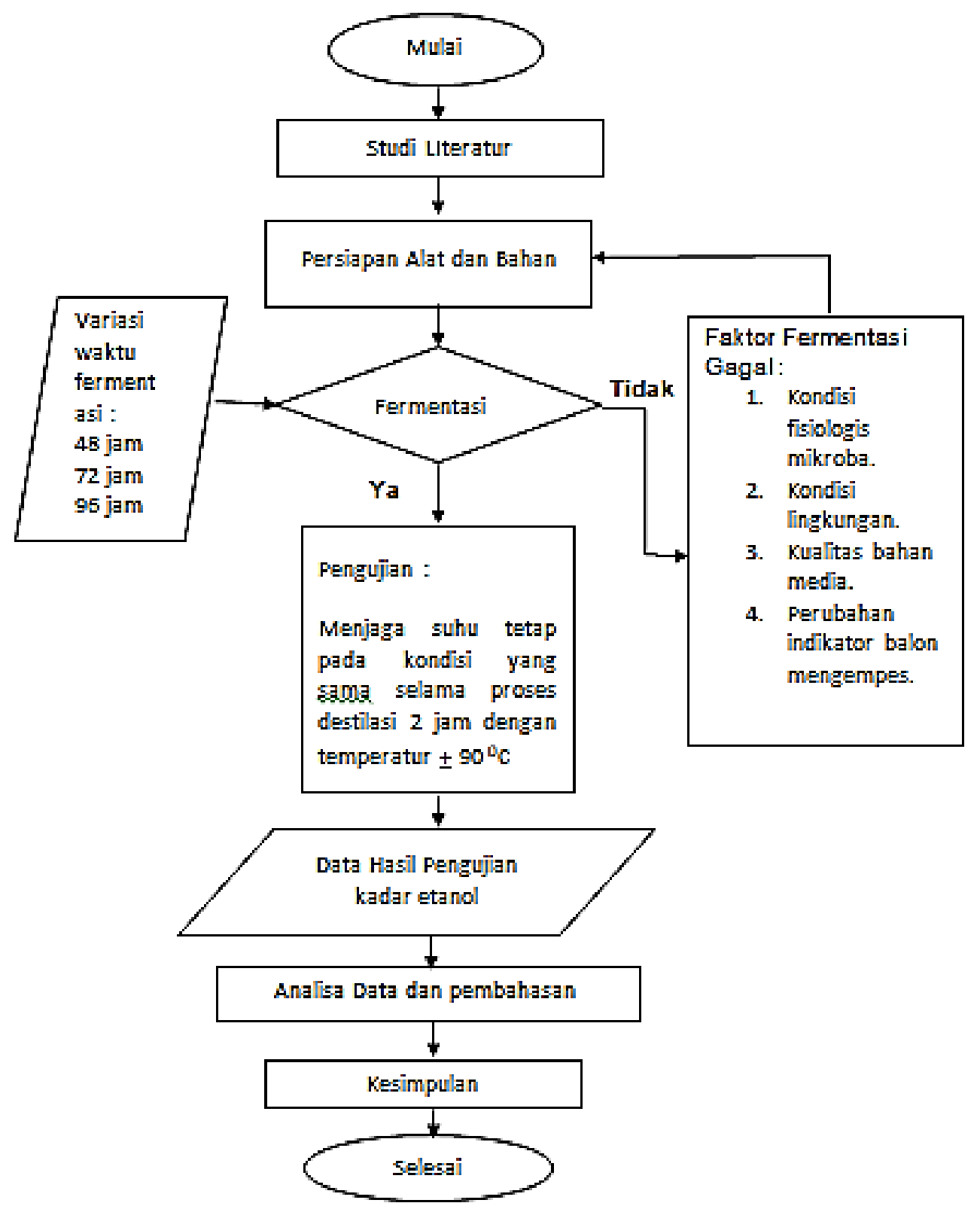

Gambar 2. Diagram Alir Penelitian

\section{HASIL DAN PEMBAHASAN}

Dalam analisa variasi waktu fermentasi terhadap kadar etanol data yang diambil merupakan kadar etanol dan volume etanol di Workshop Teknik Kimia Universitas Lambung Mangkurat dan Laboratorium Energi LPPM Institut Teknologi Sepuluh Nopember pada bulan Mei 2018 sampai dengan Juli 2018. Data penelitian ini dapat dilihat dalam Tabel 1. 
Tabel 1. Hasil data pengujian dengan pen refractometer dan gas chromatography

\begin{tabular}{|c|l|c|c|c|c|}
\hline No & \multicolumn{1}{|c|}{ Bahan } & $\begin{array}{c}\text { Massa } \\
\text { Ragi } \\
\text { (Gram) }\end{array}$ & $\begin{array}{c}\text { Waktu } \\
\text { Fermentasi } \\
\text { (Jam) }\end{array}$ & $\begin{array}{c}\text { Volume } \\
\text { Hasil } \\
\text { Destilasi } \\
(\mathbf{m l})\end{array}$ & $\begin{array}{c}\text { Kadar } \\
\text { Etanol } \\
(\%)\end{array}$ \\
\hline 1. & Singkong & 10 & 48 & 36 & 3,0 \\
\hline 2. & Singkong & 10 & 72 & 25 & 6,0 \\
\hline 3. & Singkong & 10 & 96 & 23 & 2,0 \\
\hline 4. & Beras Ketan Hitam & 10 & 48 & 20 & 8,0 \\
\hline 5. & Beras Ketan Hitam & 10 & 72 & 25 & 2,0 \\
\hline 6. & Beras Ketan Hitam & 10 & 96 & 19 & 17,50 \\
\hline 7. & Beras Ketan Putih & 10 & 48 & 25 & 2,50 \\
\hline 8. & Beras Ketan Putih & 10 & 72 & 25 & 2,0 \\
\hline 9. & Beras Ketan Putih & 10 & 96 & 21 & 8,0 \\
\hline
\end{tabular}

\section{Pengaruh Variasi Waktu Fermentasi Terhadap Kadar Etanol}

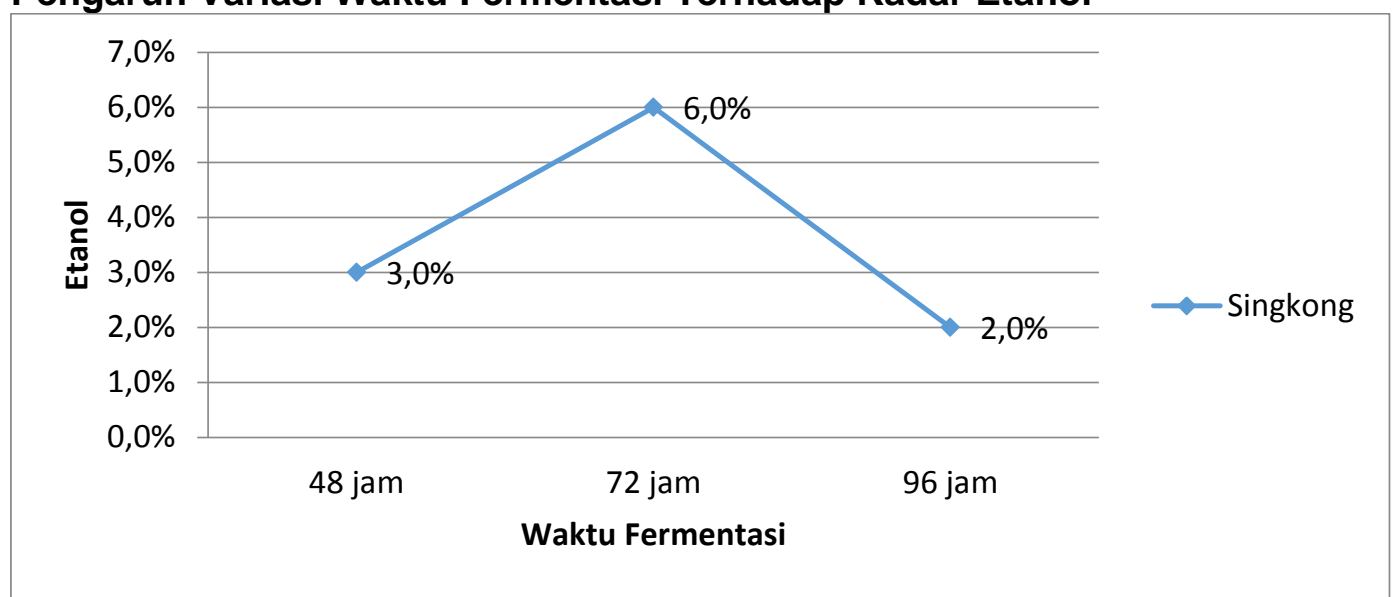

Gambar 3. Grafik Pengaruh Variasi Waktu Fermentasi Singkong Terhadap Kadar Etanol

Berdasarkan Gambar 3 pengaruh variasi waktu fermentasi singkong terhadap kadar etanol menunjukan variasi dengan waktu fermentasi yang paling cepat yaitu 48 jam mengandung kadar etanol 3,0\%, waktu fermentasi 72 jam mengandung kadar etanol $6,0 \%$, dan waktu fermentasi 96 jam mengandung kadar etanol 2,0\% dengan massa ragi yang sama yaitu 10 gram.

Dilihat pada bahan singkong dengan waktu fermentasi 96 jam kadar etanol yang dihasilkan sangat rendah. Disebabkan pertumbuhan jamur yang mengubah karbohidrat menjadi etanol yang mulai habis dan mati pada saat fermentasi berlangsung yang mengakibatkan turun nya kadar etanol, seperti yang ditunjukkan pada Gambar 7. 


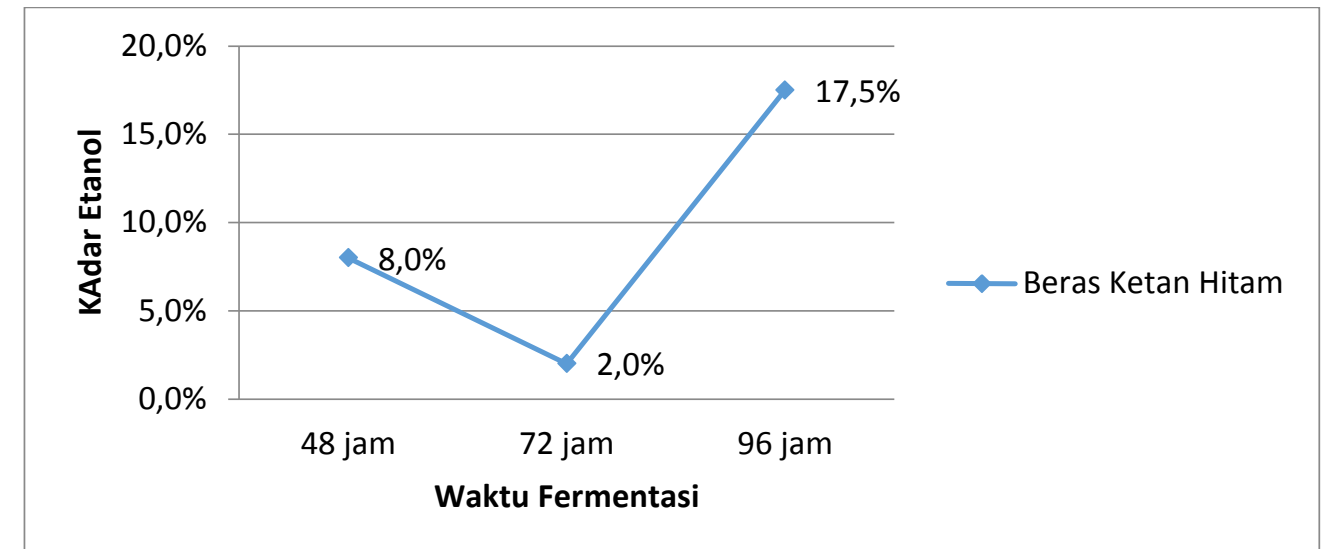

Gambar 4. Grafik Pengaruh Variasi Waktu Fermentasi Beras Ketan Hitam Terhadap Kadar Etanol

Berdasarkan Gambar 4 pengaruh variasi waktu fermentasi beras ketan hitam dengan kadar etanol menunjukan variasi dengan waktu fermentasi yang paling cepat yaitu 48 jam mengandung kadar etanol 8,0\%, waktu fermentasi 72 jam mengandung kadar etanol 2,0\%, dan waktu fermentasi 96 jam mengandung kadar etanol $17,5 \%$ dengan massa ragi yang sama yaitu 10 gram.

Dilihat pada bahan beras ketan hitam dengan waktu fermentasi 72 jam kadar etanol yang dihasilkan sangat rendah. Disebabkan pertumbuhan jamur yang merubah karbohidrat menjadi etanol yang tidak merata pada saat fermentasi berlangsung yang mengakibatkan turun nya kadar etanol, seperti yang ditunjukkan pada Gambar 8.

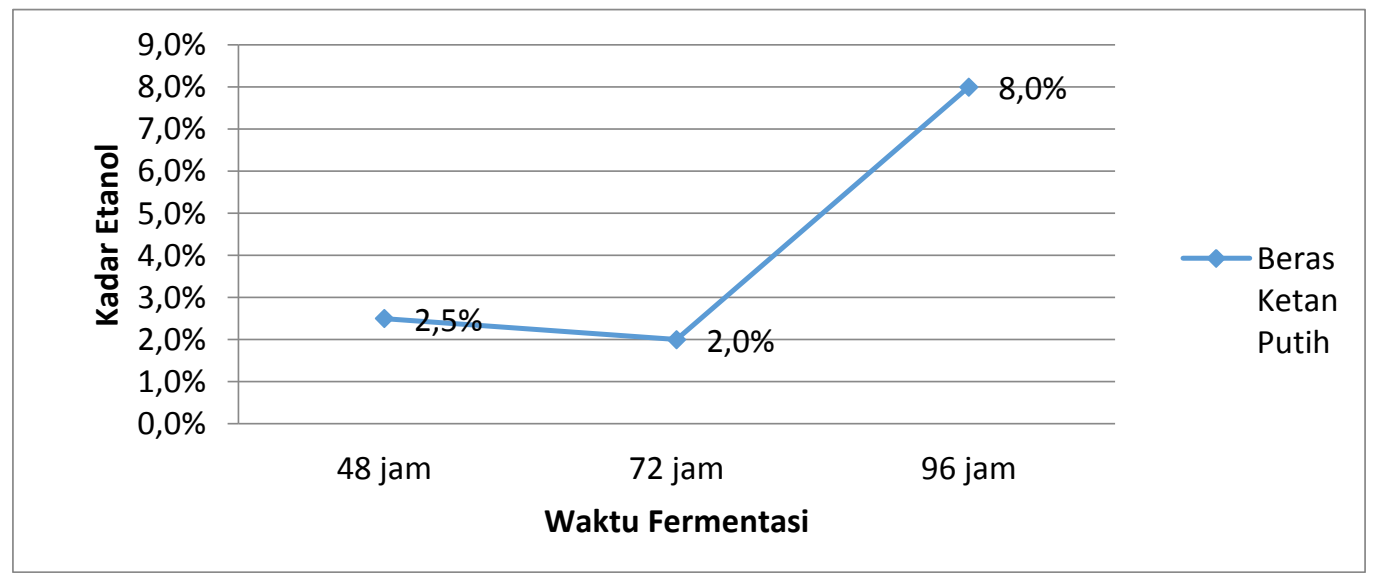

Gambar 5. Grafik Pengaruh Variasi Waktu Fermentasi Beras Ketan Hitam Terhadap Kadar Etanol

Berdasarkan Gambar 5 pengaruh variasi waktu fermentasi beras ketan putih dengan kadar etanol menunjukan variasi dengan waktu fermentasi yang paling cepat yaitu 48 jam mengandung kadar etanol 2,5\%, waktu fermentasi 72 jam mengandung kadar etanol 2,0\%, dan waktu fermentasi 96 jam mengandung kadar etanol 8,0\% dengan massa ragi yang sama yaitu 10 gram.

Dilihat pada bahanberas ketan putih dengan waktu fermentasi 72 jam kadar etanol yang dihasilkan sangat rendah. Disebabkan pertumbuhan jamur mengubah karbohidrat menjadi etanol tidak merata pada saat fermentasi 
berlangsung yang mengakibatkan turun nya kadar etanol, seperti yang ditunjukkan pada Gambar 9.

\section{Pengukuran kadar etanol dengan Gas Chromatography (GC9700)}

Berikut ini adalah hasil pengukuran kadar etanol dengan menggunakan alat Gas Chromatography.

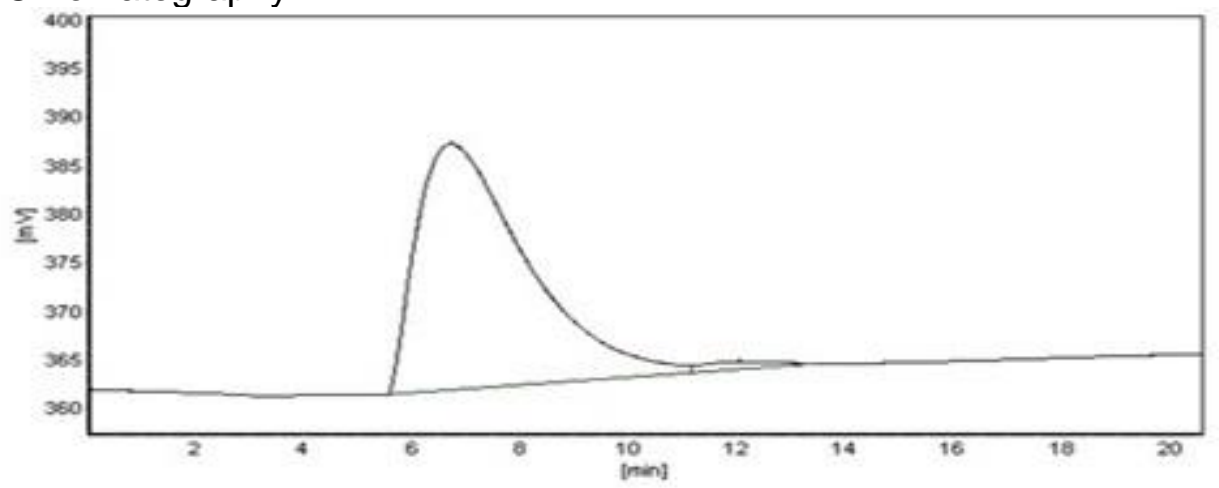

\begin{tabular}{|r|c|r|r|r|r|l|}
\hline Nos & $\begin{array}{c}\text { Compound } \\
\text { Name }\end{array}$ & R.Time & \multicolumn{1}{|c|}{ Heisht } & \multicolumn{1}{c|}{ Area } & \multicolumn{1}{c|}{ Area\% } & Type \\
\hline 1 & Ethatul & 6.71 & 25328 & 3581814 & 98.41041 & BV \\
\hline 2 & TOT.M & 12.095 & 761 & 37856 & 1.58959 & VB \\
\hline
\end{tabular}

Gambar 6. (a) Grafik Kadar Etanol Singkong Dengan Menggunakan GC

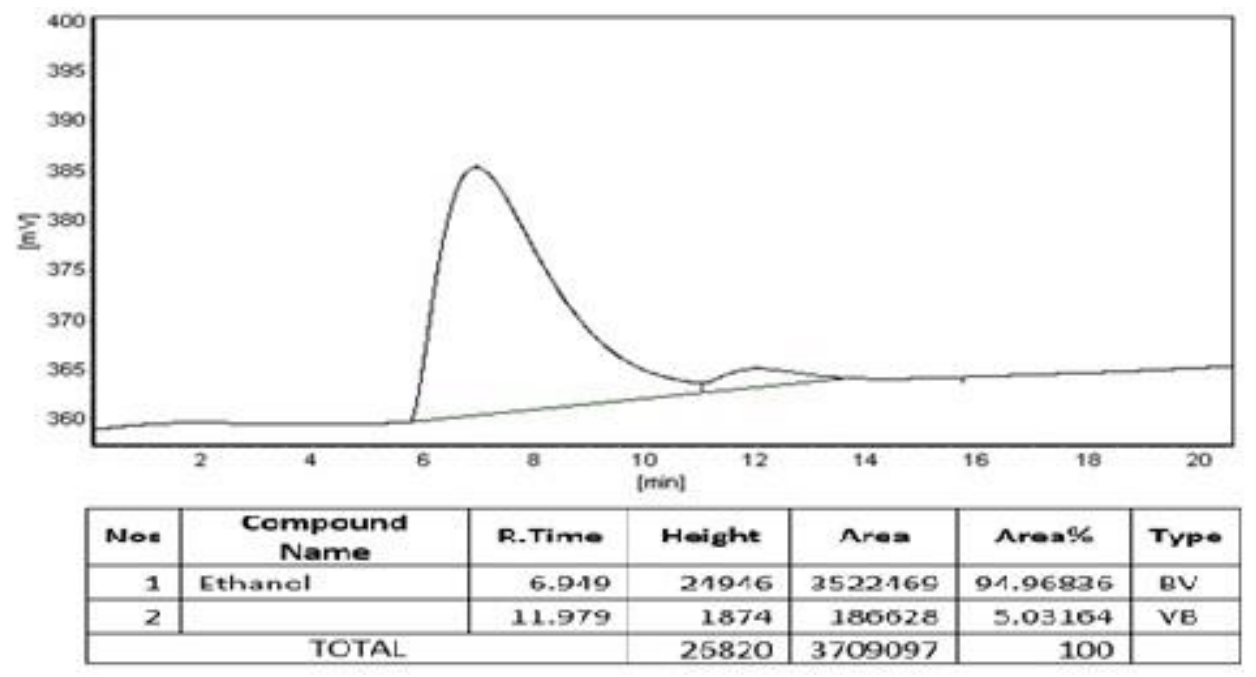

Gambar 6. (b) Grafik Kadar Etanol Beras Ketan Hitam Dengan Menggunakan GC 


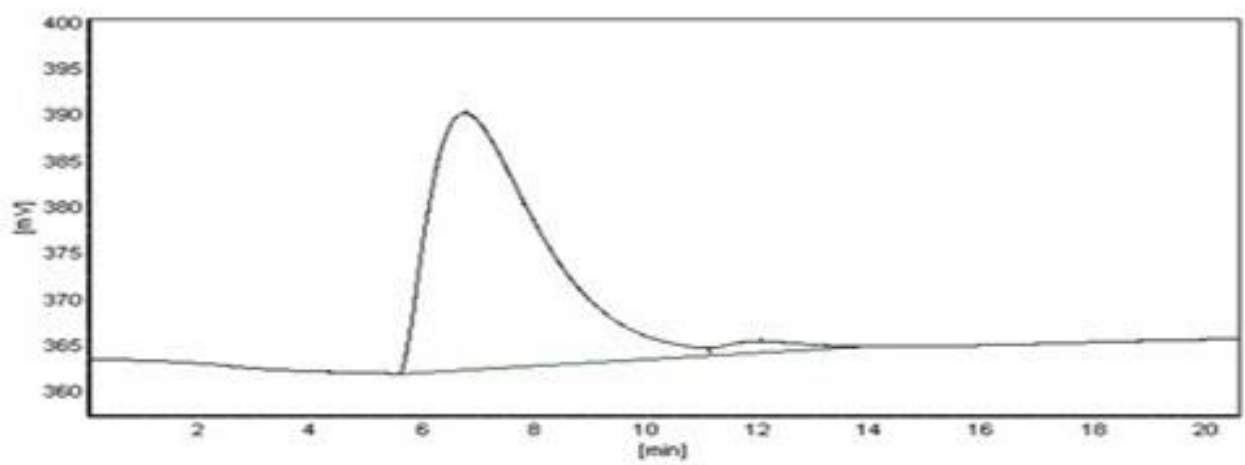

\begin{tabular}{|r|c|r|r|r|r|l|}
\hline Nos & $\begin{array}{c}\text { Compound } \\
\text { Name }\end{array}$ & R.Time & Height & \multicolumn{1}{c|}{ Area } & \multicolumn{1}{|c|}{ Area\% } & Trpe \\
\hline 1 & Ethanol & 6.747 & 27856 & 3893673 & 96.67887 & BV \\
\hline 2 & & 12.036 & 1169 & 133756 & 3.32113 & VE \\
\hline \multicolumn{2}{r}{ TOTAL } & & 29025 & 4027429 & 100 & \\
\hline
\end{tabular}

Gambar 6. (c) Grafik Kadar Etanol Beras Ketan Putih Dengan Menggunakan GC

Dari Gambar 6 a, b dan c menunjukkan hasil pengukuran etanol dengan menggunakan alat Gas Kromatografi. Pada Gambar 6(a) Singkong dengan waktu fermentasi 72 jam menunjukkan hasil kadar etanol sebesar 98,41\%, sedangkan pada Gambar 6(b) Beras Ketan Hitam dengan waktu fermentasi 96 jam menunjukkan hasil kadar etanol sebesar 94,96\% dan pada Gambar 6(c) Beras Ketan Putih dengan waktu fermentasi 96 jam menunjukkan hasil kadar etanol sebesar $96,67 \%$.

\section{Pertumbuhan Jamur Pada Proses Fermentasi}

Proses fermentasi tergantung pada pertumbuhan jamur. Jamur inilah yang berperan aktif dalam proses fermentasi dengan merombak glukosa menjadi alkohol. Menurut Widiyaningrum (2009), terjadinya pertumbuhan jamur berhubungan dengan aktifitas enzim amilase yang mengubah pati menjadi maltosa, dan dengan enzim maltase, maltosa akan dihidrolisis menjadi glukosa. Dengan adanya enzim-enzim ini Saccharomyces cerevisiae memiliki kemampuan untuk mengkonversi baik gula dari kelompok monosakarida maupun dari kelompok disakarida.

Jika gula yang tersedia dalam substrat merupakan gula disakarida maka enzim invertase akan bekerja menghidrolisis disakarida menjadi monosakarida. Setelah itu, enzim zymase akan mengubah monosakarida tersebut menjadi alkohol dan $\mathrm{CO}_{2}$.

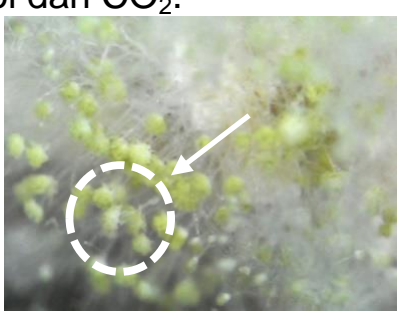

(A)

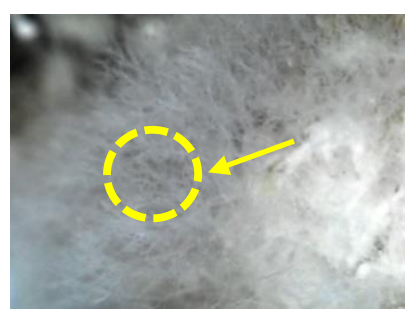

(B)

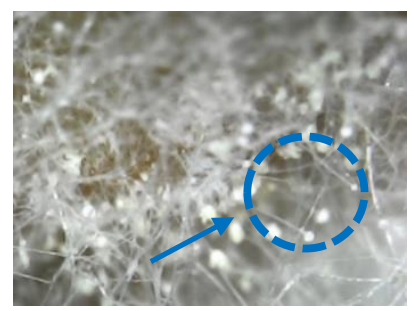

(C)

Gambar 7. Pertumbuhan Jamur Proses Fermentasi pada Singkong: (a) Waktu 48 jam, (b) Waktu 72 jam, dan (c) Waktu 96 jam

Pertumbuhan Jamur pada Singkong (48 Jam) dapat terlihat di Gambar 7(A) perkembangan jamur yang mulai bertumbuh dan berkembang terlihat pada bunga yang tumbuh ditunjukkan tanda lingkaran warna putih, dan pada Gambar 
7(B) perkembangan jamur berkembang dengan sangat banyak terlihat pada serabut yang banyak seperti ditunjukkan tanda lingkaran warna kuning. Sementara itu pada Gambar 7(C) perkembangan jamur mulai menurun terlihat pada serabut yang mulai berkurang seperti ditunjukkan tanda lingkaran warna biru.

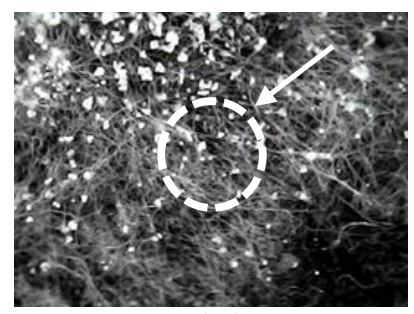

(A)

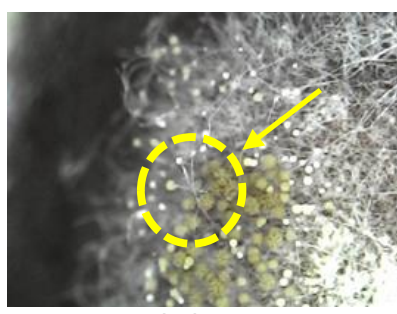

(B)

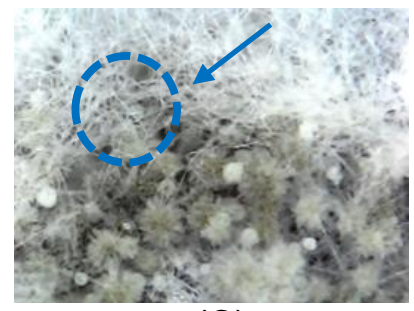

(C)

Gambar 8. Pertumbuhan Jamur Proses Fermentasi Beras Ketan Hitam (A). Waktu Fermentasi 48 Jam, (B). Waktu Fermentasi 72 Jam Dan (C). Waktu Fermentasi 96 Jam

Pertumbuhan Jamur pada Beras ketan hitam. Gambar 8(A) terlihat jamur berkembang seperti yang ditunjukkan lingkaran putih, pada Gambar 8(B) perkembangan jamur terlihat serabut bertumbuh tetapi tidak terlalu banyak seperti yang ditunjukkan Gambar kuning. Sementara itu pada Gambar 8(C) jamur berkembang terlihat dengan banyaknya serabut seperti yang ditunjukkan Gambar biru.

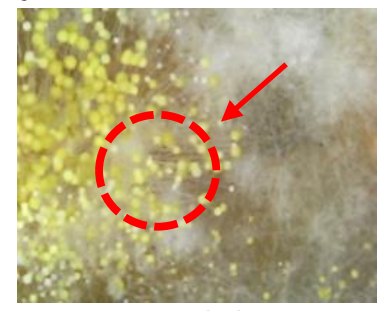

(A)

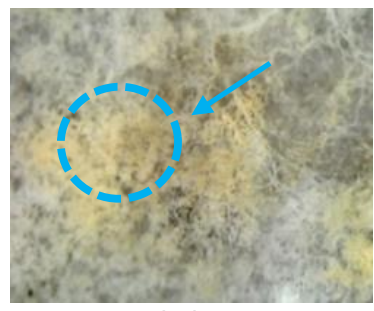

(B)

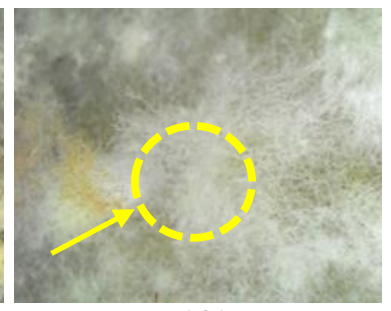

$(C)$

Gambar 9. Pertumbuhan Jamur Fermentasi Beras Ketan Putih (A). Waktu Fermentasi 48 Jam, (B). Waktu Fermentasi 72 Jam dan (C). Waktu Fermentasi 96 Jam

Pertumbuhan jamur pada beras ketan putih, terlihat pada lingkaran putih Gambar 9(A) perkembangan jamur yang mulai bertumbuh terlihat serabut mulai keluar dari bunga, dan terlihat pada lingkaran kuning Gambar 9(B) perkembangan jamur yang tidak terlalu banyak tetapi serabut sudah keluar semua dari bunganya. Sementara itu terlihat pada lingkaran biru Gambar $9(C)$ perkembangan jamur berkembang sangat pesat terlihat serabut yang sangat banyak.

Pada proses pertumbuhan jamur diatas dapat dilihat bahwa pertumbuhan jamur sangat berpengaruh dengan tinggi rendahnya etanol yang dihasilkan setelah proses fermentasi.

\section{Kualitas Kadar Etanol Menurut Standar Nasional Indonesia}

Berdasarkan data hasil pengujian di atas, kandungan etanol terbaik dari bahan singkong dengan waktu fermentasi 72 jam dengan kadar etanol 98,41\%, beras ketan hitam dengan waktu fermentasi 96 jam kadar etanolnya 94,96\%, dan beras ketan putih dengan waktu fermentasi 96 jam kadar etanolnya 96,67\%. itu di dapat setelah dilakukan pengujian etanol menggunakan alat Gas Kromatografi guna mengetahui kadar kemurnian etanol sebenarnya. 
Mengacu pada SNI 7390: 2012 yang menyatakan bahwa kadar etanol minimum yang digunakan sebagai bahan bakar jenis bioetanol sebesar (94,0 99,5\%) (Sumber: Badan Standarisasi Nasional, 2012). Etanol pada penelitian ini dapat di gunakan sebagai bahan baku pembuatan bioetanol.

\section{KESIMPULAN}

Kesimpulan yang didapatkan dari penelitian "Analisis Hasil Fermentasi Pembuatan Bioetanol Dengan Variasi Waktu Menggunakan Bahan (Singkong, Beras Ketan Hitam Dan Beras Ketan Putih adalah:

1. Proses fermentasi dalam penelitian ini dapat berjalan dan menghasilkan etanol. Hasil kadar etanol pada singkong dengan waktu fermentasi 72 jam dengan etanol sebesar $98,41 \%$, beras ketan hitam dengan waktu fermentasi 96 jam kadar etanolnya $94,96 \%$, dan beras ketan putih dengan waktu fermentasi 96 jam kadar etanolnya $96,67 \%$.

2. Mengacu pada SNI 7390: 2012, Etanol hasil fermentasi dari singkong, beras ketan hitam dan beras ketan putih pada penelitian ini termasuk kategori Standar Nasional Indonesia.

\section{DAFTAR PUSTAKA}

Anonimous, 2012. Singkong dapat memperkuat ketahanan pangan. http://www.ekon.go.id/news/2012/04/17/singkong-dapat-perkuatketahananpangan.

Badan Standarisasi Nasional (BSN). 2012. Rancangan Standar Nasional Indonesia. Jakarta.

Hasanah, H., 2008. Pengaruh Lama Fermentasi Terhadap Kadar Alkohol TapeHitam dan Tape Singkong. Skripsi. Jurusan Kimia Fakultas Sains dan Teknologi. Universitas Islam Negeri, Malang.

Lowry, O.H., et al. (1951) Protein measurement with folin phenol reagent. The Journal of Biological Chemistry, 193, 265-275.

Muhidin N.H., N. Juli, dan I.N.P. Aryantha. 2001. Peningkatan Kandungan Protein Kulit Umbi Ubi Kayu Melalui Proses Fermentasi. JMS. Vol. 6.

Prastowo, Bambang, 2007. Potensi Sektor Pertanian sebagai Penghasil dan Pengguna Energi Terbarukan (The agriculture sector as source and user of the renewable energy). Indonesia Center for Estate Crops Research and Development. Perspektif: Review Penelitian Tanaman Industri 6(2): 85-93.

Sahidin. 2008. Penuntun Praktikum Kimia Organik I. Unhalu. Kendari.

Suprihatin. 2010. Teknologi Fermentasi. UNESA University Press. Surabaya.

Widiyaningrum, C. 2009. Pengaruh Bahan Penutup Terhadap Kadar Alkohol pada Proses Bioetanol Ubi Kayu Bahan Bakar Masa Depan. Jakarta: PT. Agromedia Pustaka.

Yanuar W. 2009. Studi Aktivitas Antioksidan dan Imunomodulator Serealia Lokal Nonberas. 